\title{
Effect of Plant Growth Promoting Bacillus spp. on Germination and Seedling Growth of Soybean
}

D. Miljaković, J. Marinković, G. Tamindžić, V. Đorđević, M. Ignjatov, D. Milošević, Z. Nikolić

10.18805/LRF-665

\begin{abstract}
Background: Bacillus spp., known to promote growth and reduce disease of various field and vegetable crops, are frequently found in soils. The objective of the study was to select effective Bacillus spp. isolates with multiple plant growth properties and antifungal activities and to examine their effect on germination of soybean.

Methods: Bacterial isolates were screened for production of indole-3-acetic acid (IAA) and siderophores and solubilization of phosphate. The ability of bacterial isolates to inhibit the growth of seven phytopathogenic fungi affecting soybean was determined using a dual plate assay. Bacillus spp. were further selected and examined in a seed germination test.

Result: All Bacillus spp. isolates were positive for IAA production, while siderophore production and P-solubilization were observed in $80 \%$ and $20 \%$ bacterial isolates, respectively. Bacillus spp. exhibited the highest antifungal activity against Diaporthe caulivora, followed by Diaporthe sojae, Diaporthe eres, Diaporthe longicolla and Macrophomina phaseolina and the least antagonistic effect toward Fusarium graminearum and Fusarium subglutinans. Selected isolates of $B$. subtilis significantly affected final germination, shoot length, root length, shoot dry weight and root dry weight of two soybean cultivars. The most effective Bacillus spp. isolates could be used as potential inoculants for improving soybean productivity.

Key words: Antifungal Activity, Bacillus, Germination, PGPR, Soybean.
\end{abstract}

\section{INTRODUCTION}

Soybean [Glycine max (L.) Merrill] is one of the most important legumes in the world, providing vegetable protein, oil and nutrients for millions of people and for various purposes. As a legume, soybean has the ability to fix atmospheric nitrogen, thus reducing nitrogen fertilization and proving fit for crop rotation. Global soybean production has increased more than tenfold in the last fifty years and is constantly on the rise. Intensification of agricultural production implies the use of synthetic fertilizers and pesticides which have adverse effects on living organisms and environments (Tripathi et al., 2020). The use of plant growth promoting rhizobacteria (PGPR) represents a promising and environmentally friendly method to minimize the negative effects (Backer et al., 2018; Kaur and Kaur, 2018).

PGPR are a group of bacteria that actively colonize rhizosphere and plant roots and exert beneficial effects on plant growth, increase yield, reduce pathogen infection and mitigate biotic or abiotic stresses (Compant et al., 2010). Bacillus spp. are among the most widely reported PGPR for crop production improvement. Numerous studies of a wide range of crops showed a constant increase in the number of Bacillus spp. identified as potential plant growth promoters and biocontrol agents (Miljaković et al., 2020). Bacillus spp. can be found and successfully isolated from the soil and rhizosphere of plants. However, only a few Bacillus spp. of about 200 within the genus exhibit multiple plant growth promoting (PGP) traits as well as biocontrol activity and might be applicable in developing inoculants. Nowadays, application of inoculants in soybean production is a common and widespread agronomic practice. These
Institute of Field and Vegetable Crops, Maksima Gorkog 30, 21000 Novi Sad, Serbia.

Corresponding Author: D. Miljaković, Institute of Field and Vegetable Crops, Maksima Gorkog 30, 21000 Novi Sad, Serbia. Email: dragana.bjelic@ifvcns.ns.ac.rs

How to cite this article: Miljaković, D., Marinković, J., Tamindžić, G., Đorđević, V., Ignjatov, M., Milošević, D. and Nikolić, Z. (2022). Effect of Plant Growth Promoting Bacillus spp. on Germination and Seedling Growth of Soybean. Legume Research. DOI: 10.18805/ LRF-665.

Submitted: 06-11-2021 Accepted: 18-12-2021 Online: 07-01-2022

inoculants mostly contain symbiotic nitrogen fixing bacteria, while the use of PGPR, especially Bacillus spp., as biofertilizers and/or biopesticides in soybean production is less studied. Therefore, the aim of the study was to select effective Bacillus spp. isolates with multiple plant growth properties and antifungal activities and to determine their effect on seed germination and seedling growth of two soybean cultivars.

\section{MATERIALS AND METHODS}

The experiment was carried out in the Institute of Field and Vegetable Crops Novi Sad (IFVCNS) during 2020. Bacillus spp. used in this study were isolated from soil and identified by $16 \mathrm{~S}$ rDNA analysis and then screening of bacterial isolates for PGP traits and antifungal activity, as well as germination assays were conducted. All assays were performed in the Laboratory for Microbiological Research and Laboratory for Seed Testing (IFVCNS). 
Using the serial dilution technique, Bacillus spp. isolates were isolated from soil samples collected at different sites of the Vojvodina Province (northern Serbia) (Bjelić et al., 2018). In short, soil suspensions $(10 \mathrm{~g}$ of soil in $90 \mathrm{ml}$ of $\mathrm{dH}_{2} \mathrm{O}$ ) were serially diluted $\left(10^{-3}-10^{-6}\right)$ and $0.1 \mathrm{ml}$ aliquots were spread on plates containing nutrient agar (NA). After $48 \mathrm{~h}$ of incubation at $28^{\circ} \mathrm{C}$, isolates were characterized according to morphological and biochemical properties and subjected to molecular identification based on PCR analysis of 16S rDNA sequences (Bjelić et al., 2018). Each isolate was deposited in the NCBI GenBank database under a unique accession number (Table 1). Bacterial cultures were collected and stocked on NA slants at $4^{\circ} \mathrm{C}$. Bacillus spp. isolates for assays were cultured for $24 \mathrm{~h}$ in nutrient broth (NB), at optimal temperature of $28^{\circ} \mathrm{C}$. Culture suspension contained $10^{9}$ of colony forming units per $\mathrm{ml}(\mathrm{CFU} \mathrm{ml})^{-1}$ ).

Screening for PGP properties in Bacillus spp. isolates included determination of their capability to produce indole3-acetic acid (IAA) and siderophores and to dissolve sparingly soluble inorganic phosphate. For quantitative analysis of indole-3-acetic acid (IAA) production, a $100 \mu \mathrm{l}$ $24 \mathrm{~h}$-old bacterial suspension was inoculated in the nutrient broth (NB), supplemented with 0 and $250 \mu \mathrm{g} \mathrm{ml}^{-1}$ of Ltryptophan (HiMedia, India). Salkowski reagent $\left(\mathrm{FeCl}_{3}-\right.$ $\mathrm{HClO}_{4}$ : $2 \% 0.5 \mathrm{M}$ ferric chloride in $35 \%$ perchloric acid) was mixed with the supernatant $(2: 1 \mathrm{v} / \mathrm{v})$ and intensity of the developed color was measured at $530 \mathrm{~nm}$ (Glickman and Dessaux, 1995). Bacterial ability to produce siderophores was assayed on Chromeazurol S (CAS) (Himedia, India) medium by observing changes of the color zones (greenblue to orange) (Milagres et al., 1999). The capability of Bacillus spp. to dissolve sparingly soluble inorganic phosphate was determined on Pikovskaya medium (PVK) (Pikovskaya, 1948) and National Botanical Research Institute's phosphate growth medium (NBRIP) (Nautiyal, 1999 ) with $0.5 \%$ tricalcium phosphate $\left[\mathrm{Ca}_{3}\left(\mathrm{PO}_{4}\right)_{2}\right]$.

The antifungal activity of Bacillus spp. isolates against phytopathogenic fungi originally isolated from soybean seeds was examined using a dual plate assay (Zhao et al., 2010). Investigated fungi were: Macrophomina phaseolina, Diaporthe longicolla, Diaporthe caulivora, Diaporthe sojae, Diaporthe eres, Fusarium graminearum, Fusarium subglutinans. Bacterial suspension was steaked on potato dextrose agar (PDA), while tested fungus (7-day-old mycelial plugs on PDA, $R=6 \mathrm{~mm}$ ) was aseptically transferred on the same plate. After incubation, the percent of growth inhibition (PGI) was calculated according to the formula:

$$
\mathrm{PGI}(\%)=\frac{\mathrm{C}-\mathrm{R} 1}{\mathrm{C}} \times 100
$$

Where

C and R1 represent growth of mycelium in control and dual culture. Assays for each bacterium and fungus were performed in three replicates.

The effect of Bacillus spp. on seed germination and initial seedling development was examined using a standard germination test (ISTA, 2020). Seeds of soybean cultivars Teona and Atlas, developed at the IFVCNS, were used for test. Seeds were surface disinfected in $5 \%$ sodium hypochlorite $(\mathrm{NaOCl})$ for $5 \mathrm{~min}$, rinsed with sterile distilled water four times and then dried back on sterile filter paper under aseptic conditions. Inoculation of seeds was performed with $10 \mathrm{ml}$ of Bacillus suspension $\left(10^{9} \mathrm{ml}^{-1}\right)$. Noninoculated seeds were control. Four replicates of 100 treated seeds were germinated on a moistened filter paper in plastic boxes $240 \times 150 \mathrm{~mm}$ and placed in a germination chamber at $25^{\circ} \mathrm{C}$ for 8 days. Treatments were arranged in a completely randomized block design. Energy of germination was determined 5 days after sowing, while seed germination, shoot and root length were determined 8 days after sowing. To determine dry weight, samples were oven-dried at $80^{\circ} \mathrm{C}$ for 24 hours.

Data were analyzed by analysis of variance (ANOVA) using the statistical software package STATISTICA 12.0 (StatSoft Inc., Oklahoma, USA). The differences among various treatment means were compared using the Tukey's test at $5 \%(P<0.05)$ probability level.

\section{RESULTS AND DISCUSSION}

In this study, ten Bacillus spp. isolates were used for PGP and antifungal activity assays (Table 1).

Screening for characteristics commonly associated with plant growth promotion revealed that the tested bacterial isolates were able to produce IAA in a range of 5.41 to 45.09 $\mu \mathrm{g} \mathrm{ml}^{-1}$ (Table 2). All Bacillus spp. isolates produced IAA in the medium without L-tryptophan and the amount of produced IAA increased with concentration of precursor in the medium. Isolates of $B$. subtilis B5 and B32 were the best IAA producers, in both media. The ability of bacteria to produce IAA indicates their potential use as plant hormones or plant regulators (Spaepen and Vanderleyden, 2011).

PGPR have evolved specialized mechanisms for the assimilation of iron, including the production of siderophores. Additionaly, siderophores act as biocontrol and bioremedation agents (Miljaković et al., 2020). The ability of Bacillus spp. to produce siderophores was detected for all isolates except $B$. pumilus B22 and B23. The largest

Table 1: Isolates of Bacillus spp. from soil samples collected at different locations at northern Serbia.

\begin{tabular}{llc}
\hline Isolate code & \multicolumn{1}{c}{ Species } & NCBI accession number \\
\hline B2 & Bacillus safensis & KU953932 \\
B3 & Bacillus pumilus & KU953923 \\
B5 & Bacillus subtilis & KU953925 \\
B7 & Bacillus subtilis & KU953927 \\
B11 & Bacillus pumilus & KU953931 \\
B13 & Bacillus subtilis & KX444639 \\
B21 & Bacillus pumilus & KX444647 \\
B22 & Bacillus pumilus & KX444648 \\
B23 & Bacillus pumilus & KX444649 \\
B32 & Bacillus subtilis & KX766373 \\
\hline
\end{tabular}


production zone was measured for $B$. subtilis $\mathrm{B} 5$ (>15 mm), followed by $B$. safensis $\mathrm{B} 2, B$. pumilus $\mathrm{B} 3$ and $\mathrm{B} 11, B$. subtilis $\mathrm{B} 7, \mathrm{~B} 32(5-15 \mathrm{~mm})$, B. subtilis B13 and B. pumilus B21 (1$5 \mathrm{~mm}$ ) (Table 2).

PGPR solubilize insoluble inorganic $P$ and mineralize insoluble organic $P$, thus enhancing plant growth and $P$ uptake by plants. Bacillus spp. are among the most prospective P-solubilization microorganisms (Sharma et al., 2013). In this study, solubility of $\mathrm{Ca}_{3}\left(\mathrm{PO}_{4}\right)_{2}$ on PVK and NBRIP has been determined for $B$. subtilis $B 5$ and $B 7$, with solubilization zone 4-7 $\mathrm{mm}$ and 1-4 $\mathrm{mm}$, respectively (Table 2).

The tested isolates of Bacillus spp. exhibited strong antifungal activity against seven soybean pathogens (Table 3). The highest antagonistic effect was obtained by confrontation of Bacillus spp. with Diaporthe caulivora, followed by Diaporthe sojae, Diaporthe eres, Diaporthe longicolla and Macrophomina phaseolina, while antifungal activity was the lowest against Fusarium graminearum and Fusarium subglutinans (average PGI ranged from $14.7 \%$ to $55.2 \%$ ). The antifungal activity of particular Bacillus spp. depended on the investigated fungi. On average, the highest biocontrol potential toward soybean pathogens was observed for $B$. subtilis isolates B5, B7 and $\mathrm{B} 32(47.4 \%, 49.3 \%$ and $47.2 \%$ reduction in fungal growth, respectively). Previous studies showed very strong antifungal activity of B. subtilis B5, B7 and B32 against Fusarium tricinctum, F. oxysporumf. sp. cepae, $F$. proliferatum, $F$. verticillioides and $F$. acuminatum, isolated from infected garlic cloves (Bjelić et al., 2018). Similarly, Rani et al. (2021) observed that Bacillus showed

Table 2: Plant growth promoting properties of Bacillus spp. isolates from soil samples collected at different locations at northern Serbia.

\begin{tabular}{|c|c|c|c|c|c|}
\hline \multirow[t]{2}{*}{ Isolate } & \multicolumn{2}{|c|}{$\begin{array}{c}\text { IAA }\left(\mu \mathrm{g} \mathrm{ml}^{-1} \pm \mathrm{SD}\right) \text { at different } \\
\text { L-tryptophan concentrations }\left(\mu \mathrm{ml}^{-1}\right)\end{array}$} & \multirow[t]{2}{*}{ Siderophores } & \multicolumn{2}{|c|}{ P-solubilization } \\
\hline & 0 & 250 & & $(\mathrm{PVK})$ & (NBRIP) \\
\hline Bacillus safensis B2 & $5.44^{\mathrm{g}}$ & $14.78^{9}$ & ++ & nd & nd \\
\hline Bacillus pumilus B3 & $5.41^{g}$ & $15.30^{\mathrm{e}}$ & ++ & nd & nd \\
\hline Bacillus subtilis B5 & $11.09^{a}$ & $45.09^{a}$ & +++ & ++ & ++ \\
\hline Bacillus subtilis B7 & $6.28^{e}$ & $16.80^{c}$ & ++ & + & + \\
\hline Bacillus pumilus B11 & $5.90^{f}$ & $15.67^{d}$ & ++ & nd & nd \\
\hline Bacillus subtilis B13 & $6.45^{d}$ & $15.66^{d}$ & + & nd & nd \\
\hline Bacillus pumilus B21 & $7.32^{c}$ & $13.01^{\mathrm{h}}$ & + & nd & nd \\
\hline Bacillus pumilus B22 & $6.41^{\mathrm{d}}$ & $15.14^{f}$ & nd & nd & nd \\
\hline Bacillus pumilus B23 & $6.49^{d}$ & $14.64^{9}$ & nd & nd & nd \\
\hline Bacillus subtilis B32 & $9.57^{\mathrm{b}}$ & $18.20^{\mathrm{b}}$ & ++ & nd & nd \\
\hline
\end{tabular}

Means with different lowercase letters in the same column are significantly different $(p<0.05$, Tukey test); Siderophores: $(+) 1-5 \mathrm{~mm}$ wide of orange zone, $(++) 5-15 \mathrm{~mm}$ wide of orange zone, $(+++)>15 \mathrm{~mm}$ wide of orange zone; P-solubilization: $(+)$ 1-4 mm of halo diameter, $(++)$ 4-7 mm of halo diameter; (nd) not detected.

Table 3: Antifungal activity of Bacillus spp. isolates from soil samples collected at different locations at northern Serbia.

\begin{tabular}{|c|c|c|c|c|c|c|c|c|}
\hline \multirow[t]{2}{*}{ Isolate } & $\begin{array}{c}\text { Macro- } \\
\text { phomina } \\
\text { phaseolina }\end{array}$ & $\begin{array}{l}\text { Diaporthe } \\
\text { longicolla }\end{array}$ & $\begin{array}{l}\text { Diaporthe } \\
\text { caulivora }\end{array}$ & $\begin{array}{l}\text { Diaporthe } \\
\text { sojae }\end{array}$ & $\begin{array}{c}\text { Diaporthe } \\
\text { eres }\end{array}$ & $\begin{array}{c}\text { Fusarium } \\
\text { grami } \\
\text {-nearum }\end{array}$ & $\begin{array}{c}\text { Fusarium } \\
\text { subglutinans }\end{array}$ & Average \\
\hline & \multicolumn{8}{|c|}{ Per cent of growth inhibition (\%) } \\
\hline Bacillus safensis B2 & $31.8^{d}$ & $45.5^{\mathrm{ab}}$ & $60.4^{c}$ & $64.7^{\mathrm{b}}$ & $47.8^{\mathrm{cd}}$ & $51.4^{\mathrm{a}}$ & - & 43.1 \\
\hline Bacillus pumilus B3 & $51.8^{\mathrm{a}}$ & $44.3^{\mathrm{abc}}$ & $62.3^{\mathrm{bc}}$ & $52.9^{d}$ & $53.3^{a}$ & - & - & 37.8 \\
\hline Bacillus subtilis B5 & $38.8^{b}$ & $42.3^{\mathrm{bcd}}$ & $59.2^{c}$ & $58.8^{c}$ & $48.6^{\mathrm{bc}}$ & $48.2^{\mathrm{bc}}$ & $35.7^{\mathrm{b}}$ & 47.4 \\
\hline Bacillus subtilis B7 & $49.8^{\mathrm{a}}$ & $38.8^{d}$ & $60.4^{c}$ & $64.7^{\mathrm{b}}$ & $50.9^{\mathrm{ab}}$ & $50.6^{\mathrm{ab}}$ & $30.2^{c}$ & 49.3 \\
\hline Bacillus pumilus B11 & $34.1^{\mathrm{cd}}$ & $42.3^{\mathrm{bcd}}$ & $53.3^{d}$ & $69.4^{a}$ & $45.1^{\text {de }}$ & - & - & 34.9 \\
\hline Bacillus subtilis B13 & $36.5^{\mathrm{bc}}$ & $40.0^{\text {cd }}$ & $62.3^{\mathrm{bc}}$ & $38.8^{\mathrm{e}}$ & $49.8^{\mathrm{bc}}$ & - & $35.3^{b}$ & 37.5 \\
\hline Bacillus pumilus B21 & $35.7^{\mathrm{bc}}$ & $44.7^{\mathrm{ab}}$ & $66.7^{a}$ & $53.3^{d}$ & $44.3^{\mathrm{e}}$ & - & - & 35.0 \\
\hline Bacillus pumilus B22 & $34.5^{\mathrm{cd}}$ & $44.3^{\mathrm{abc}}$ & $64.7^{\mathrm{ab}}$ & $60.4^{c}$ & $48.6^{\mathrm{bc}}$ & - & - & 36.1 \\
\hline Bacillus pumilus B23 & - & $48.6^{a}$ & - & - & $33.7^{9}$ & - & - & 11.8 \\
\hline Bacillus subtilis B32 & $35.7^{\mathrm{bc}}$ & $44.7^{\mathrm{ab}}$ & $62.3^{b c}$ & $56.8^{\mathrm{cd}}$ & $39.6^{f}$ & $45.9^{c}$ & $45.5^{\mathrm{a}}$ & 47.2 \\
\hline Average & 34.9 & 43.5 & 55.2 & 52.0 & 46.2 & 19.6 & 14.7 & \\
\hline Isolate & $* *$ & $* *$ & $* *$ & $* *$ & $* *$ & $* *$ & $* *$ & \\
\hline
\end{tabular}

Means with different lowercase letters in the same column are significantly different $\left(p<0.05\right.$, Tukey's test); ${ }^{* *}-$ significance at 0.01 probability level. 
Effect of Plant Growth Promoting Bacillus spp. on Germination and Seedling Growth of Soybean

Table 4: Analysis of variance for germination parameters of soybean under different cultivar and bacterial treatments.

\begin{tabular}{lcccccc}
\hline -value & $\begin{array}{c}\text { Germination } \\
\text { viability }(\%)\end{array}$ & $\begin{array}{c}\text { Final germination } \\
(\%)\end{array}$ & $\begin{array}{c}\text { Shoot length } \\
(\mathrm{mm})\end{array}$ & $\begin{array}{c}\text { Root length } \\
(\mathrm{mm})\end{array}$ & $\begin{array}{c}\text { Shoot dry } \\
\text { weight }(\mathrm{g})\end{array}$ & $\begin{array}{c}\text { Root dry } \\
\text { weight }(\mathrm{g})\end{array}$ \\
\hline Cultivar (C) & 0.000 & 0.000 & 0.007 & 0.000 & 0.012 & 0.107 \\
Bacteria (B) & 0.097 & 0.002 & 0.004 & 0.000 & 0.004 & 0.000 \\
$\mathrm{C} \times \mathrm{B}$ & 0.032 & 0.017 & 0.487 & 0.000 & 0.386 & 0.000 \\
\hline
\end{tabular}

Table 5: Effect of selected Bacillus isolates from soil samples collected at different locations at northern Serbia on seed germination and seedling growth of soybean.

\begin{tabular}{|c|c|c|c|c|c|c|c|}
\hline Cultivar & Treatment & $\begin{array}{l}\text { Germination } \\
\text { viability (\%) }\end{array}$ & $\begin{array}{c}\text { Final } \\
\text { germination (\%) }\end{array}$ & $\begin{array}{c}\text { Shoot } \\
\text { length }(\mathrm{mm})\end{array}$ & $\begin{array}{c}\text { Root } \\
\text { length (mm) }\end{array}$ & $\begin{array}{l}\text { Shoot dry } \\
\text { weight (g) }\end{array}$ & $\begin{array}{l}\text { Root dry } \\
\text { weight (g) }\end{array}$ \\
\hline \multirow[t]{4}{*}{ Teona } & Control & $80.0^{\mathrm{ab}}$ & $88.3^{\text {bc }}$ & $116.2^{c}$ & $129.6^{\mathrm{e}}$ & $0.73^{b}$ & $0.17^{c}$ \\
\hline & Bacillus subtilis B5 & $82.8^{a}$ & $90.3^{a b c}$ & $125.6^{\mathrm{abc}}$ & $135.1^{\text {de }}$ & $0.90^{\mathrm{ab}}$ & $0.17^{\mathrm{bc}}$ \\
\hline & Bacillus subtilis $\mathrm{B} 7$ & $79.0^{\mathrm{ab}}$ & $92.8^{\mathrm{ab}}$ & $121.9^{a b c}$ & $153.1^{\mathrm{bc}}$ & $0.88^{\mathrm{ab}}$ & $0.21^{\mathrm{a}}$ \\
\hline & Bacillus subtilis B32 & $88.0^{a}$ & $98.0^{\mathrm{a}}$ & $120.9^{a b c}$ & $183.5^{\mathrm{a}}$ & $0.87^{a b}$ & $0.22^{\mathrm{a}}$ \\
\hline Average & & 83.3 & 93.7 & 122.8 & 157.2 & 0.88 & 0.20 \\
\hline \multirow[t]{4}{*}{ Atlas } & Control & $65.3^{c}$ & $78.3^{d}$ & $119.1^{\mathrm{bc}}$ & $98.1^{f}$ & $0.83^{\mathrm{ab}}$ & $0.12^{\mathrm{d}}$ \\
\hline & Bacillus subtilis B5 & $72.3^{\mathrm{bc}}$ & $86.8^{\mathrm{bc}}$ & $130.3^{\mathrm{ab}}$ & $166.5^{\mathrm{b}}$ & $0.98^{a}$ & $0.21^{\mathrm{ab}}$ \\
\hline & Bacillus subtilis B7 & $71.0^{\mathrm{bc}}$ & $85.0^{\mathrm{bcd}}$ & $133.0^{\mathrm{a}}$ & $152.1^{\mathrm{bc}}$ & $1.01^{a}$ & $0.20^{\mathrm{abc}}$ \\
\hline & Bacillus subtilis B32 & $67.0^{c}$ & $82.8^{\mathrm{cd}}$ & $125.3^{\mathrm{abc}}$ & $146.3^{\text {cd }}$ & $0.89^{\mathrm{ab}}$ & $0.19^{a b c}$ \\
\hline Average & & 70.1 & 84.9 & 129.5 & 155.0 & 0.96 & 0.20 \\
\hline
\end{tabular}

Means with different lowercase letters in the same column are significantly different $(p<0.05$, Tukey's test).

maximum zone of inhibition to the tested pathogen among the three antagonistic biocontrol agents.

Three isolates of $B$. subtilis B5, B7 and B32 with the highest PGP and biocontrol potential were selected for further examination of their effect on soybean seed germination and seedling growth. Plant growth promotion is crucial in early developmental stages such as germination and seedling growth (Gholami et al., 2009). Establishment of PGPR in plant rhizosphere and soil could lead to an increase in biomass and grain production in later developmental stages (Compant et al. 2010). This study showed that investigated cultivars had significant effect on germination viability, final germination, shoot length, root length and shoot dry weight, while bacterial treatments significantly affected final germination, shoot length, root length, shoot dry weight and root dry weight. Interaction of experimental factors also had significant effect on tested germination parameters, except shoot length and shoot dry weight (Table 4).

Application of selected $B$. subtilis isolates improved seed quality compared to control, in both cultivars (Table 5). On average, bacterial treatments resulted in an increase in germination viability $(4 \%$ and $7 \%)$, final germination $(6 \%$ and $8 \%)$, shoot length $(6 \%$ and $9 \%)$, root length $(21 \%$ and $58 \%)$, shoot dry weight $(21 \%$ and $16 \%)$ and root dry weight $(18 \%$ and $67 \%)$. The highest increase of germination viability and final germination was achieved by $B$. subtilis B32 (10\% and $11 \%)$ of cv. Teona and B5 (11\% and $11 \%)$ of cv. Atlas. Isolate $B$. subtilis B5 led to the highest increase of shoot length and shoot dry weight ( $8 \%$ and $23 \%$ ) of $\mathrm{cv}$. Teona, as well as root length and root dry weight $(70 \%$ and $75 \%)$ of cv. Atlas. Isolate $B$. subtilis B32 had the best effect on root length and root dry weight $(42 \%$ and $23 \%)$ of $\mathrm{cv}$. Teona, while treatment with isolate B7 caused the highest increase in shoot length and shoot dry weight (12\% and $22 \%$ ) of cv. Atlas.

Similarly to these results, Bahadir et al. (2018) reported that the best $\mathrm{P}$-solubilizing and IAA-producing isolates of $B$. subtilis had positive effects on the seed germination and vegetative growth parameters of eggplant, pepper and tomato, while the studies of Yu et al. (2011) indicated that siderophores produced by Bacillus spp. were involved in suppression of plant diseases along with promotion of plant growth. Bacillus species perform dual functions by showing antagonism against plant pathogens and displaying plant growth promoting properties, which could be highly advantageous in developing the best possible inoculants for soybean, especially if applied in combination with the symbiotic bacteria. Recently, a beneficial effect of Bacillus subtilis and Bradyrhizobium japonicumon plant growth was reported by Kiruthika and Arunkumar (2020), probably due to the IAA production, P-solubilization and siderophore production. Similarly, Singh and Singh (2018) observed that co-inoculation with PGPR and rhizobia is a promising strategy for the enhancement of plant absorption of $\mathrm{P}$, as well as plant growth and grain yield.

\section{CONCLUSION}

Based on our results, the indigenous Bacillus spp. isolates from soil generally had good PGP and biocontrol potential. Application of the selected $B$. subtilis isolates resulted in an increase of germination parameters in the two tested 
soybean cultivars. In general, the best effect on the tested germination parameters was observed after seed inoculation with $B$. subtilis $B 5$ and $B 32$ isolates as superior IAA and siderophore producers. These isolates have the potential as PGP and biocontrol agents of soybean. Further selection of the most effective strains through field trials will be necessary to establish their efficiency as individual and combined inoculants in certain environmental conditions.

\section{ACKNOWLEDGEMENT}

The authors would like to thank Dr. Kristina Petrovic of the Maize Research Institute Zemun Polje for the identification of fungi.

\section{Funding}

This research was supported by the Ministry of Education, Science and Technological Development of the Republic of Serbia, grant number: 451-03-9/2021-14/200032.

\section{REFERENCES}

Backer, R., Rokem, J.S., Ilangumaran, G., Lamont, J., Praslickova, D., Ricci, E., Subramanian, S., Smith, D.L. (2018). Plant growth-promoting rhizobacteria: Context, mechanisms of action and roadmap to commercialization of biostimulants for sustainable agriculture. Frontiers in Plant Science. 9: 1473.

Bahadir, P.S., Liaqat, F., Eltem, R. (2018). Plant growth promoting properties of phosphate solubilizing Bacillusspecies isolated from the Aegean Region of Turkey. Turkish Journal of Botany. 42: 1-14.

Bjelić, D., Ignjatov, M., Marinković, J., Milošević, D., Nikolić, Z., Gvozdanović-Varga, J., Karaman, M. (2018). Bacillus isolates as potential biocontrol agents of Fusarium clove rot of garlic. Zemdirbyste-Agriculture. 105: 369-376.

Compant, S., Clément, C., Sessitsch, A. (2010). Plant growthpromoting bacteria in the rhizo- and endosphere of plants: their role, colonization, mechanisms involved and prospects for utilization. Soil Biology and Biochemistry. 42: 669-678.

Gholami, A, Shahsavani, S, Nezarat, S. (2009). The effect of plant growth promoting rhizobacteria (PGPR) on germination, seedling growth and yield of maize. International Journal of Biological, Biomolecular, Agricultural, Food and Biotechnological Engineering. 3: 9-14.

Glickman, E. and Dessaux, Y. (1995). A critical examination of the specificity of the Salkowski reagent for indolic compounds produced by phytopathogenic bacteria. Applied and Environmental Microbiology. 61: 793-796.

ISTA (2020): International Rules for Seed Testing. Seed Science and Technology. Zurich, Switzerland.
Kaur, R. and Kaur, S. (2018). Biological alternates to synthetic fertilizers: Efficiency and future scopes. Indian Journal of Agricultural Research. 52: 587-595.

Kiruthika, S. and Arunkumar, M. (2020). A comprehensive study on IAA production by Bradyrhizobium japonicum and Bacillus subtilis and its effect on Vigna radiata plant growth. Indian Journal of Agricultural Research. 55: 570-576.

Milagres, A.F.M., Machuca, A., Napoleao, D. (1999). Detection of siderophore production from several fungi and bacterial by a modifcation of chrome azurol S (CAS) agar plate assay. Journal of Microbiological Methods. 37: 1-6.

Miljaković, D., Marinković, J., Balešević-Tubić, S. (2020). The significance of Bacillus spp. in disease suppression and growth promotion of field and vegetable crops. Microorganisms. 8: 1037.

Nautiyal, C.S. (1999). An effcient microbiological growth medium for screening phosphate solubilizing microorganisms. FEMS Microbiology Letters. 170: 265-270.

Pikovskaya R.I. (1948). Mobilization of phosphorus in soil in connection with the vital activity of some microbial species. Mikrobiologiya. 17: $362-370$.

Rani, A., Upadhyay, S.K., Shukla, G.,Singh, C. Singh, R. (2021). Efficacy of bacterial isolates against causal agent of late blight of potato, Phytophthorainfestans. Indian Journal of Agricultural Research. 55: 403-409.

Sharma, S.B., Sayyed, R.Z., Trivedi, M.H., Gobi, T.A. (2013). Phosphate solubilizing microbes: Sustainable approach for managing phosphorus deficiency in agricultural soils. SpringerPlus. 2: 587.

Singh, N. and Singh, G. (2018). Plant growth promoting rhizobacteria and Rhizobium combinations are the key to reduce dependence on phosphorus fertilizers in lentil-A review. Agricultural Reviews. 39: 76-81

Spaepen, S. and Vanderleyden, J. (2011). Auxin and plant-microbe interactions. Cold Spring Harbor Perspectives in Biology. 3: a001438.

Tripathi, S., Srivastavab, P., Devi, R.S., Bhadouria, R. (2020). Influence of synthetic fertilizers and pesticides on soil health and soil microbiology. In: Agrochemicals Detection, Treatment and Remediation. Vara Prasad M.N., Heinemann B. (eds.). p. 25-54.

Yu, X., Ai, C., Xin, L., Zhou, G. (2011). The siderophore-producing bacterium, Bacillus subtilis CAS15, has a biocontrol effect on Fusarium wilt and promotes the growth of pepper. European Journal of Soil Biology. 47: 138-145.

Zhao, Z., Wang, Q., Wang, K., Brian, K., Liu, C., Gu, Y. (2010). Study of the antifungal activity of Bacillus vallismortis ZZ185 in vitro and identification of its antifungal components. Bioresource Technology. 101: 292-297. 